\title{
Correlation of Emotional Intelligence with Conflict Management Styles in IT based Organization
}

\author{
Goodwill Khokhar ${ }^{1} *$, William Selvamurthy ${ }^{2}$
}

\section{ABSTRACT}

Background and objectives: Conflict Management (CM) has emerged as a great challenge in the corporate sector due to several recent psycho-social changes. Emotional Intelligence (EI) may have considerable influence on CM styles. Methods: We have studied this aspect on 100 volunteers of both genders in the age ranging from 25 to 50 years serving in Human Resource and Administration wing of an IT based organization. Standard questionnaire was used to measure Emotional Quotient Index (EQI) (Self Rating) and EQI (Observer Rating) and Conflict Management styles using Rahim Organizational Level Conflict Inventory II. Results: There was a significant influence of EI on problem solving, asserting, compromising and accommodating styles of CM. Conclusion: EI Has significant influence on CM styles. This study has opened up much potential application of EI measurement in recruitment and training of supervisors and senior managers.

Keywords: Emotional Intelligence, Conflict Management styles

In the recent years corporate sector encounters many challenges such as high level of business competition, fast turnover of human resource, deficiency in leadership and numerous conflicts in the organization. Timely resolution of Conflicts applying appropriate Conflict Management (CM) styles [1] will result in creating a congenial organizational climate leading to performance enhancement and profit achievement. Earlier research has indicated possible relationship between Emotional Intelligence (EI) [2] and subordinates' style of handling conflict with supervisors [3]. These studies reported that Integrating style (both parties finding a creative solution to satisfy both parties' concerns) and the compromising style (both parties winning some and losing some in an attempt to reach a consensus) of CM will be generally applied by the subordinates if they have supervisors with high EI.

\footnotetext{
${ }^{1}$ Master's of General Psychology, Manager, Amity Science Technology \& Innovation Foundation (ASTIF), Amity University, Noida, Uttar Pradesh, India

${ }^{2}$ PhD, Physiology \& D.Sc., Yoga Psychology, President, ASTIF, Amity University, Noida, Uttar Pradesh, India *Responding Author

(C) 2016 I G Khokhar, W Selvamurthy; licensee IJIP. This is an Open Access Research distributed under the terms of the Creative Commons Attribution License (http://creativecommons.org/licenses/by/2.0), which permits unrestricted use, distribution, and reproduction in any Medium, provided the original work is properly cited.
} 
EI plays a vital role in an organisation because it creates a congenial and vibrant organisational climate among the employees. Goleman (2004) stated that those employees with high EI are "Star Performers"[4]. However strong criticism has also been raised against such claims as these lack adequate empirical data support [5].According to Goleman (1998) the five components of EI are Self Awareness (SA), Self-Regulation (SR),Social Skills (SS) Motivation (MO) and Empathy (EM)[2].According to Rahim (1986) the five styles of resolving conflicts in preparation for negotiation are Integrating (IN), Obliging (OB),Dominating (DO) Avoiding (AV) and Compromising (CO)[6].In a recent study by Sergio, Dungca \& Ormita (2015) strong relationship of EI with work values was demonstrated [7].In effective leadership we cannot presume that Intelligent Quotient (IQ) and technical ability are the only important variables to achieve high performance; EI is also important for leaders to make a supervisor equipped with sufficient leadership skills and hence all the three facets need to be attended [8].

It will be interesting to correlate the five dimensions of EI with those of CM styles. The other aspect which has not been clearly understood is the level of convergence between self-rating of EI and the observer rating of EI. Hence, we have undertaken the present study for correlation of these two important factors namely EI domains and CM styles in an IT based Indian corporate sector organization. The reason for selecting an IT based organization is that India has a large number of IT industries who are employing a vast pool of young human resource and are prospering globally.

\section{RESEARCH METHOD}

\section{Subjects}

The present study was conducted on 100 volunteers in Human Resources Division and Administration Division of an IT based corporate sector organization. Of these 100 participants who responded to the questionnaire survey 57 were males while 43 were females. They were of age ranging from 25 to 50 years with $44 \%$ in the age group of 30-40 years. They were well educated with $20 \%$ of the subjects having Doctoral (Ph.D) qualification, 63\% a Master's degree and the rest were graduates. Among the participants 42 were Supervisors while 58 were subordinates working with them.

\section{Research Instruments}

\section{Emotional Quotient Index (EQI) (Self Rating) Survey}

It is a standardized survey tool for self-assessment which can be used for both supervisors and subordinates to assess their EI level by themselves. This tool is based on Goleman's five domains of EI i.e., Self-Awareness, Self-Regulation, Motivation, Empathy and Social Skills [2]. There are 14 items in the survey tool with 7 point Likert scale ('7' indicating 'strongly agree' and ' 1 ' is rated as 'strongly disagree'). Some examples of the items in the Survey tool are:

\section{* As source of wisdom I take both positive and negative emotions to take my decision}

* From moment to moment I can monitor my life 


\section{Emotional Quotient Index (Observer Rating) Survey}

Supervisor's EQ was measured using the tool at the organization as against their personality profile. Goleman's five domains of EI formed the basis of the survey tool as mentioned above. Generally items in EQI (Observer Rating) are the same as in EQI (Self Rating) substituting "I" by "my supervisor". Some samples of items are as follows:

* Under pressure my boss keeps himself/herself calm

* Depending on with whom my boss is interacting he/she adjusts his/her Behavior

\section{Rahim Organizational Conflict Inventory-II (ROCI-II) Form A Survey}

This inventory was developed by Rahim (1983) with 28 items for assessing CM styles [6]. It is a survey tool developed by Rahim et al. (2002) which can evaluate Emotional Quotient (EQ) of supervisor at work against their personality profile [9]. It is based on all five domains of EI described by Goleman (1998). This survey also contains 14 items and uses 7 point Likert scale with ' 1 ' being 'strongly disagree' and ' 7 ' being 'strongly agree'. Some of the sample items are given below:

* To understand the true and genuine feelings of others I readily tell my Boss

* To smoothly handle multiple demands and shifting priorities I readily tell my boss

\section{Data Collection Procedure}

The above mentioned survey questionnaires were carefully prepared for ease of use by volunteers of the study. All subjects were briefed about the objectives and methods to be adopted in the study. They were given a consent form for the confirmation that they clearly understood the study procedure and objective. One week time was provided to subjects to fill and complete the survey questionnaire.

\section{Data Analysis}

Data were analyzed using Excel to weigh and score responses of participants, and subsequently were subjected to using SSPS Regression to evaluate the relationship between EI and CM styles.

\section{RESULTS}

EI domains among Supervisors and Subordinates are shown in Table-1. Awareness OR scores were significantly $(\mathrm{p}<0.04)$ higher in Supervisors as compared to Subordinates, while other domains of EI did not exhibit any significant difference. Multiple correlations of EI domains among themselves and also with CM styles are shown in Table-2. SR scores of EI domains are highly $(\mathrm{P}<0.01)$ correlated among themselves. On the other hand, comparison of SR scores of EI domains with those of OR scores were only limited. For example, Awareness SR score positively correlated with Empathy and Social skills $(\mathrm{P}<0.01)$ while it did not show any correlation with Awareness OR score, Regulation score and Motivation score. There was high correlation of Awareness SR score with Collaborating and Accommodating CM styles (Table-2).However Motivation SR score was also correlated positively with Compromising CM style $(\mathrm{P}<0.01)$. It is 


\section{Correlation of Emotional Intelligence with Conflict Management Styles in IT based Organization}

interesting to note that Social Skills SR score exhibited a positive correlation with all styles of CM except Accommodating style of CM. Awareness OR score showed positive correlation with Accommodating and Avoiding styles of CM. Motivation OR scores were highly $(\mathrm{P}<0.01)$ correlated with Accommodating, Competing and Avoiding styles of CM. Age does not show any correlation with the EI domains or CM styles.

\section{Table 1}

\begin{tabular}{|l|l|l|l|}
\hline Variable & N & Mean & SD \\
\hline Awareness_SR & 100 & 14.53 & 2.901 \\
\hline Regulation_SR & 100 & 15.82 & 2.524 \\
\hline Motivation_SR & 100 & 10.41 & 1.980 \\
\hline Empathy_SR & 100 & 15.80 & 3.101 \\
\hline Social Skills_SR & 100 & 16.34 & 2.753 \\
\hline Awareness_OR & 100 & $15.69^{*}$ & 2.759 \\
\hline Regulation_OR & 100 & 16.20 & 2.331 \\
\hline Motivation_OR & 100 & 10.67 & 1.918 \\
\hline Empathy_OR & 100 & 15.91 & 2.613 \\
\hline Social Skills_OR & 100 & 16.49 & 2.873 \\
\hline
\end{tabular}

$* \mathbf{P}<\mathbf{0 . 0 4}$

\section{DISCUSSION}

EI is a multidimensional construct composed of different and somewhat distinct abilities from Intelligent Quotient [10]. When Salovey \& Mayer (1990) carried out a comprehensive test to establish EI as one of the intelligence, they found that intellect and EI were different because they use different parts of the brain [11]. Goleman (2004) discovered that EI capabilities are the main reason for the effectiveness of a star performer based on a study of competency models from 188 companies. He stated that self-regulation, a component of EI is crucial for leaders because it enables them to create an environment of trust and fairness [4]. Not only that, but they would be able to master their emotions in competitive situations, and enhance integrity for both personal virtue and organizational strength. Empathy on the other hand, plays an effective role in leadership for three reasons: increasing use of teams, rapid pace of globalization and growing need to retain talents [4]. Social Skills is considered as a key leadership capability because it is a culmination of other components of EI and it motivates people in a desired direction. In our study Self Awareness among supervisors was higher $(\mathrm{p}<0.04)$ than in the subordinates (Table-1). Other four domains of EI did not exhibit any difference between SR scores and OR scores indicating a higher coherence between self-rating and observer rating for EI.

Palmer et al., (2000) found that several components of transformational leadership are correlated with EI particularly among leaders who concentrate on simple reward and punishment [12].

(C) The International Journal of Indian Psychology, ISSN 2348-5396 (e)| ISSN: 2349-3429 (p) | 24 


\section{Correlation of Emotional Intelligence with Conflict Management Styles in IT based Organization}

However in the study of Weinberger (2002) such a correlation could not be established [13]. Employees who have high levels of EI have smoother interaction with the members of their work teams [5] thereby creating harmonious environment in the organization. Leadership effectiveness is highly dependent on EI as the leader is able to influence the followers through social skills, empathy and motivation [14].

Effective CM can lead to desired organizational outcomes such as fairness, satisfaction, effectiveness and efficiency [15]. Gross et al., (1996) rated integrating style of CM as the most effective while avoiding style as the least effective [16]. Cultural difference was also observed in application of various CM styles [1]. Arab Middle Eastern executives used more of avoiding and integrating styles whereas US executives were using the dominating, obliging and compromising styles in handling conflict with their supervisors. Arab Easterners exhibit a high value on privacy and incline to avoid conflict while US executives nurture individualism dimension [1]. In our study Indian executives are observed to use more of collaborating, accommodating and compromising styles of CM which also exhibit correlation with EI domains (Table-2). This is a positive facet of organizational culture in IT organization in India which could be an important factor for the global success of Indian IT sector.

$\mathrm{Yu}$ et. al., (2006) showed that intelligence of supervisors was positively associated with subordinates' use of integrating, compromising and dominating styles of handling conflicts with the supervisors, while integrating style can be most predicted by EI [3]. In their model of EI and CM styles found that the five components of EI are correlated with each other [9]. Findings of our study are also in conformity with these observations (Table-2). We found that SR scores of EI domains are highly correlated among themselves $(\mathrm{p}<0.01)$. We also observed that there was considerable level of divergence between SR of EI with OR scores (Table-2) indicating that the coherence between self-perception of EI and others perception was rather limited.

Social skills emerged as the most significant EI domain which positively correlated with all styles of CM except accommodating style (table-2). Motivation is another domain of EI which has showed significant $(\mathrm{P}<0.01)$ correlation with compromising style. Hence in the training for leadership or supervisory position emphasis needs to be laid on developing these skills $[17,18]$.

Leadership effectiveness also depends on EI and thinking preference [6,12] In a recent study by Akbar et.al(2014)on employees of youth and sport department of east Azarbayjan province a strong relationship was established between intergroup conflicts and EI [19]. In our study on IT professionals in India similar correlation was observed (Table-2).

In our study we observed motivation $(\mathrm{OR})$ was $(\mathrm{P}<0.01)$ correlated with accommodating, competing and avoiding styles (table-2). Barbuto and Ye (2006) developed a structural model using sources of motivation, CM styles and leadership effectiveness [20]. In another study on 


\section{Correlation of Emotional Intelligence with Conflict Management Styles in IT based Organization}

employees of Telecom sctor in Pakistan, EI was observed to influence the performance of employees in customer services [21].

Our study revealed that EI has positive correlation with CM styles (Table-2) and hence EI may be used as a predictor of CM styles. Similar findings were also recently reported by Kumari (2015) [22], and Pandey et.al., (2015) [23]. Effective negotiation skills which are also part of attributes of leadership were found to be beneficial in conflict resolution in Nigerian University environment [24]. Similarly a number of recent studies have clearly established a very good correlation between EI and CM [25,26,27,28].

Thus in the present study we have clearly demonstrated a positive relationship between EI and CM styles. It will open up many potential application of applying EI measurement in recruitment of supervisors, senior managers and officials for leadership role. During Training Need Analysis (TNA) in an organization particularly at senior level, requirement of EI development also needs to be assessed. Congenial organizational behavior can be created through above measures which will enhance motivation, retention and performance of employees leading to profitability in a corporate organization.

\section{Acknowledgment:}

We thank Dr. N. Ramachandran, Director, Defence Institute of Psychological Research (DIPR), Delhi and Dr. A Suresh Scientist, DIPR, Delhi for their valuable help in statistical analysis of data. We express our grateful thanks to the volunteers of the study from XYZ Corporate sector Organization for their wholehearted cooperation in the study.

\section{Conflict of Interests}

The author declared no conflict of interests.

\section{REFERENCES}

1. Elsayed-Ekhouly, S.M., \& Buda, R. (1996) Organisational conflict: a comparative analysis of conflict styles across cultures. The International Journal of Conflict Management. 7, 71-81.

2. Goleman, D. (1998). Working with Emotional Intelligence. New York: Bantum Books.

3. Yu, C.S, Sardessai, R. M., Lu, I., \& Zhao, J.H. (2006). Relationship of emotional intelligence with conflict management styles: an empirical study in China. International Journal Management and Enterprise Development, 3, 19-29.

4. Goleman, D. (2004). What makes a leader? Harvard Business Review, 82, 82-91.

5. Mayer, J.D., Caruso. D.R., \& Salovey, P. (2000). Emotional Intelligence meets traditional standards for an intelligence. Intelligence, 27, 267-29

6. Rahim, M.A. (1983). Rahim Organisational Conflict Inventories: Professional Manual. Palo Alto, CA, USA: Consulting Psychologists. 


\section{Correlation of Emotional Intelligence with Conflict Management Styles in IT based Organization}

7. Sergio, R.P., Dungca, A.L., \& Ormita, L.A.G. (2015). The demographic variables and emotional intelligence as correlates of work values: A Cross- Cultural examination towards organizational change. Journal of Economics, Business and Management 3, 167-175.

8. Herbst, T.H., \& Maree, K.G. (2008). Thinking style preference, emotional intelligence and leadership effectiveness. SA Journal of Industrial Psychology, 34, 32-41.

9. Rahim, M.A., Psenicka, C., Polychroniou, P., Zhao, J.H., Yu, C.S., Chan, K.A., \& Renewan Wyke, R. (2002). A model of emotional intelligence and conflict management studies. The International Journal of Organisational Analysis, 10, 302-332.

10. Riggio, R.E., \& Reichard, R.J. (2008). The emotional and social intelligence of effective leadership: an emotional and social skill approach. Journal of Managerial Psychology, 23, 169-185.

11. Salovey, P., \& Mayer, J. (1990). Emotional intelligence. Imagination, Cognition and Personality, 9, 185-221.

12. Palmer, B., Walls, M., Burgess, Z., \& Stough, C. (2000). Emotional intelligence and effective leadership. Leadership and Organisational Development Journal, 22, 5-10.

13. Weinberger, L.A. (2002). Emotional intelligence: its connections to HRD theory and practice. Human Resource Development Review, 1, 215-243.

14. Kerr, R., Garvin, J., Heaton, N., \& Boyle, E. (2006). Emotional intelligence and leadership effectiveness. Leadership \& Organisation Development Journal, 27, 265-279.

15. Jameson, I. (1999). Toward a comprehensive model for the assessment and management of intra-organisational conflict: developing the framework. The International Journal of Conflict Management, 10, 268-294.

16. Gross, M., Guerrero, L., \& Hair, E. (1996). Managing conflict appropriately and effectively: an application of the competency model to Rahim's organisational conflict styles. The International Journal of Conflict Management, 3, 200-226.

17. Langley,A.,(2000).Emotional Intelligence a new evaluation for management development. Career Development International, 5(3), 177-183.

18. Hess, J.D \& Bacigalupo, A.C. (2011). Enhancing decisions and decision making processes through the application of emotional intelligence skills. Management Decision, 49 (5) 710-721

19. Akbar, A., Laya, M. \& Gargari, A.S. (2014). The relationship between emotional intelligence and inter groups conflicts among employees of youth and sport departments of east Azarbayjan province. Indian Journal of Fundamental and Applied Life Sciences, 4(S3) 808-813.

20. Barbuto, J, \& Ye, X. (2006). Sources of motivation, interpersonal conflict management styles \& leadership effectiveness: A structural model. Psychological Reports, 98(1), 3-20.

21. Chughtai, M.W. \& Lateef, K. (2015). Role of emotional intelligence on Employees performance in Customer services: A case study of telecom sector of Pakistan. 


\section{Correlation of Emotional Intelligence with Conflict Management Styles in IT based Organization}

International Journal of Advance Research in Computer Science and Management Studies. 3(2) 101-108.

22. Kumari, N. (2015). Emotional intelligence as a predictor of conflict resolution style. Research Journal of Business Management 9(2), 350-363

23. Pandey, S., Sajjanapu, S. \& Sangwan (2015). Study on effect of emotional intelligence on conflict resolution style. Indian Journal of Science and Technology, 8(S6), 71-81.

24. Oredein, A.O. \& Eigbe, M. (2014). Leadership negotiation skill as correlate of university conflict resolution in Nigeria. Procedia - Social and Behavioral Sciences, 112: 12371245.

25. Schlaerth, A., Ensari, N. \& Christian, J. (2013) A meta-analytical review of the relationship between emotional intelligence and leaders' constructive conflict management. Group Process \& Intergroup Relations. 16 (1) 126-136.

26. Shamoradi, S.N., Jahangiri, P., Chahardoli, T., Tirafkan, K. (2014). Studying the effect of emotional intelligence on conflict management styles. Kuwait Chapter of Arabian Journal of Business and Management Review, 4(1), 390-400.

27. Sobhi, Z. N. \& Jenaabadi, H. (2015). Relationship of emotional intelligence with conflict management and Job stress of nurses. The Social Sciences 10(6): 1208-1216.

28. Srinivasan, P. T. \& George, S. (2005). A study on the relationship of emotional intelligence and conflict management styles among management students. The Vision Journal of Management and Allied Sciences, 11 (4), 1-6.

\section{Appendix I}

Table 2: Significance and correlation of Emotional Intelligence with Conflict Management

Observations: Multiple correlations of EI domains among themselves and also with CM styles are shown in Table-8. SR scores of EI domains are highly $(\mathrm{P}<0.01)$ correlated among themselves. On the other hand, comparison of SR scores of EI domains with those of OR scores were only limited. For example, Awareness SR score positively correlated with Empathy and Social skills $(\mathrm{P}<0.01)$ while it did not show any correlation with Awareness OR score, Regulation score and Motivation score. There was high correlation of Awareness SR score with Collaborating and Accommodating CM styles (Table-8). However Motivation SR score was also correlated positively with Compromising $\mathrm{CM}$ style $(\mathrm{P}<0.01)$. It is interesting to note that Social Skills SR score exhibited a positive correlation with all types of CM except Accommodating type of CM. Awareness OR score showed positive correlation with Accommodating and Avoiding types of CM. Motivation OR scores were highly $(\mathrm{P}<0.01)$ correlated with Accommodating, Competing and Avoiding styles of CM. Age does not show any correlation with the EI domains or CM styles. 


\section{Correlation of Emotional Intelligence with Conflict Management Styles in IT based Organization}

\section{Correlations}

\begin{tabular}{|c|c|c|c|c|c|c|c|c|c|c|c|c|c|c|c|c|c|}
\hline & & 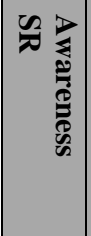 & 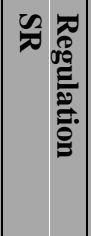 & 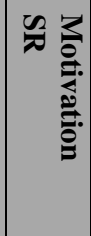 & 兄 & 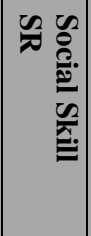 & 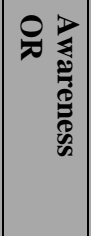 & 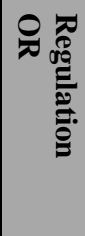 & 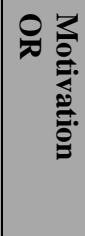 & 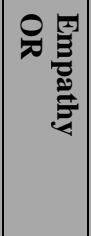 & 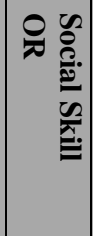 & 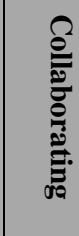 & 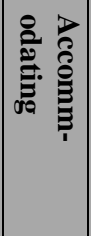 & 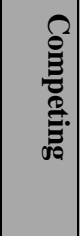 & 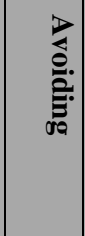 & 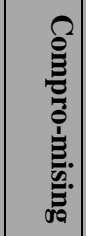 & 总 \\
\hline \multirow{3}{*}{ D } & $\begin{array}{l}\text { Pearson } \\
\text { Correlation }\end{array}$ & 1 & $.659^{* *}$ & $.699^{* *}$ & $.490^{* *}$ & $.515^{* *}$ & .119 & .125 & .119 & $.094^{* *}$ & $.109^{* *}$ & $.170^{* *}$ & $.176^{* *}$ & .083 & .145 & -.050 & $-.013^{* *}$ \\
\hline & $\begin{array}{l}\text { Sig. (2- } \\
\text { tailed) }\end{array}$ & & .000 & .000 & .000 & .000 & .237 & .217 & .239 & .351 & .280 & .091 & .080 & .414 & .150 & .624 & .895 \\
\hline & $\mathrm{N}$ & 100 & 100 & 100 & 100 & 100 & 100 & 100 & 100 & 100 & 100 & 100 & 100 & 100 & 100 & 100 & 100 \\
\hline \multirow{3}{*}{ 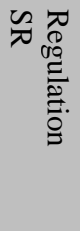 } & $\begin{array}{l}\text { Pearson } \\
\text { Correlation }\end{array}$ & $.659^{* *}$ & 1 & $.678^{* *}$ & $.555^{* *}$ & $.589^{* *}$ & .136 & .186 & $.163^{* *}$ & .141 & $.121^{* *}$ & $.088^{* *}$ & $.068^{* *}$ & .112 & .012 & $.063^{* *}$ & .097 \\
\hline & $\begin{array}{l}\text { Sig. (2- } \\
\text { tailed) }\end{array}$ & .000 & & .000 & .000 & .000 & .179 & .063 & .105 & .160 & .231 & .383 & .500 & .265 & .903 & .536 & .337 \\
\hline & $\mathrm{N}$ & 100 & 100 & 100 & 100 & 100 & 100 & 100 & 100 & 100 & 100 & 100 & 100 & 100 & 100 & 100 & 100 \\
\hline \multirow{3}{*}{ 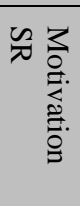 } & $\begin{array}{l}\text { Pearson } \\
\text { Correlation }\end{array}$ & $.699^{* *}$ & $.678^{* *}$ & 1 & $.668^{* *}$ & $.511^{* *}$ & .184 & .126 & $.198^{* *}$ & $.050^{* * *}$ & .082 & $.192^{* *}$ & $.221^{* * *}$ & .167 & .102 & $.051^{* *}$ & $.093^{* *}$ \\
\hline & $\begin{array}{l}\text { Sig. (2- } \\
\text { tailed) } \\
\end{array}$ & .000 & .000 & & .000 & .000 & .066 & .210 & .048 & .620 & .420 & .056 & .027 & .098 & .313 & .613 & .358 \\
\hline & $\mathrm{N}$ & 100 & 100 & 100 & 100 & 100 & 100 & 100 & 100 & 100 & 100 & 100 & 100 & 100 & 100 & 100 & 100 \\
\hline \multirow{3}{*}{ 正罗 } & $\begin{array}{l}\text { Pearson } \\
\text { Correlation }\end{array}$ & $.490^{* *}$ & $.555^{* *}$ & $.668^{* *}$ & 1 & $.558^{* *}$ & .128 & .081 & $.133^{* *}$ & $.092^{* *}$ & $.139^{* *}$ & .066 & $.169^{* *}$ & .141 & .015 & $.109^{* *}$ & $.191^{* *}$ \\
\hline & $\begin{array}{l}\text { Sig. (2- } \\
\text { tailed) } \\
\end{array}$ & .000 & .000 & .000 & & .000 & .203 & .423 & .187 & .360 & .167 & .516 & .092 & .163 & .878 & .279 & .057 \\
\hline & $\mathrm{N}$ & 100 & 100 & 100 & 100 & 100 & 100 & 100 & 100 & 100 & 100 & 100 & 100 & 100 & 100 & 100 & 100 \\
\hline \multirow{3}{*}{ 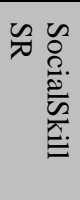 } & $\begin{array}{l}\text { Pearson } \\
\text { Correlation }\end{array}$ & $.515^{* *}$ & $.589^{* *}$ & $.511^{* *}$ & $.558^{* *}$ & 1 & $.232^{*}$ & $.205^{*}$ & $.320^{* *}$ & $.279^{* *}$ & $.220^{* *}$ & $.088^{* *}$ & .089 & $.190^{*}$ & $.104^{*}$ & $.065^{* * *}$ & $.172^{* *}$ \\
\hline & $\begin{array}{l}\text { Sig. (2- } \\
\text { tailed) }\end{array}$ & .000 & .000 & .000 & .000 & & .020 & .041 & .001 & .005 & .028 & .385 & .381 & .059 & .303 & .518 & .086 \\
\hline & $\mathrm{N}$ & 100 & 100 & 100 & 100 & 100 & 100 & 100 & 100 & 100 & 100 & 100 & 100 & 100 & 100 & 100 & 100 \\
\hline \multirow{3}{*}{ 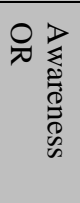 } & $\begin{array}{l}\text { Pearson } \\
\text { Correlation }\end{array}$ & .119 & .136 & .184 & .128 & $.232^{*}$ & 1 & $.541^{* *}$ & .622 & .492 & .306 & .034 & $.149^{*}$ & .099 & $.081^{* *}$ & .183 & .118 \\
\hline & $\begin{array}{l}\text { Sig. (2- } \\
\text { tailed) }\end{array}$ & .237 & .179 & .066 & .203 & .020 & & .000 & .000 & .000 & .002 & .733 & .139 & .330 & .426 & .069 & .243 \\
\hline & $\mathrm{N}$ & 100 & 100 & 100 & 100 & 100 & 100 & 100 & 100 & 100 & 100 & 100 & 100 & 100 & 100 & 100 & 100 \\
\hline \multirow{3}{*}{ 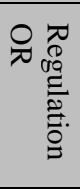 } & $\begin{array}{l}\text { Pearson } \\
\text { Correlation }\end{array}$ & .125 & .186 & .126 & .081 & $.205^{*}$ & $.541^{* *}$ & 1 & .602 & .606 & .634 & .033 & $.196^{*}$ & $104^{* * *}$ & .113 & .038 & .075 \\
\hline & $\begin{array}{l}\text { Sig. (2- } \\
\text { tailed) }\end{array}$ & .217 & .063 & .210 & .423 & .041 & .000 & & .000 & .000 & .000 & .743 & .051 & .302 & .262 & .706 & .459 \\
\hline & $\mathrm{N}$ & 100 & 100 & 100 & 100 & 100 & 100 & 100 & 100 & 100 & 100 & 100 & 100 & 100 & 100 & 100 & 100 \\
\hline \multirow{3}{*}{ 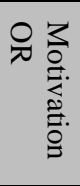 } & $\begin{array}{l}\text { Pearson } \\
\text { Correlation }\end{array}$ & .119 & .163 & $.198^{*}$ & .133 & $.320^{* *}$ & $.622^{* *}$ & $.602^{* *}$ & 1 & .695 & $.534^{*}$ & .036 & $.133^{* *}$ & $.134^{* *}$ & $\begin{array}{c}- \\
.029^{* *}\end{array}$ & .202 & -.036 \\
\hline & $\begin{array}{l}\text { Sig. (2- } \\
\text { tailed) }\end{array}$ & .239 & .105 & .048 & .187 & .001 & .000 & .000 & & .000 & .000 & .721 & .188 & .185 & .778 & .044 & .725 \\
\hline & $\mathrm{N}$ & 100 & 100 & 100 & 100 & 100 & 100 & 100 & 100 & 100 & 100 & 100 & 100 & 100 & 100 & 100 & 100 \\
\hline \multirow{3}{*}{ 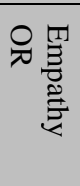 } & $\begin{array}{l}\text { Pearson } \\
\text { Correlation }\end{array}$ & .094 & .141 & .050 & .092 & $.279^{* *}$ & $.492^{* *}$ & $.606^{* *}$ & .695 & 1 & .714 & .059 & $.040^{* *}$ & $143^{* * *}$ & $.011^{* *}$ & .097 & -.048 \\
\hline & $\begin{array}{l}\text { Sig. (2- } \\
\text { tailed) }\end{array}$ & .351 & .160 & .620 & .360 & .005 & .000 & .000 & .000 & & .000 & .560 & .691 & .157 & .910 & .336 & .635 \\
\hline & $\mathrm{N}$ & 100 & 100 & 100 & 100 & 100 & 100 & 100 & 100 & 100 & 100 & 100 & 100 & 100 & 100 & 100 & 100 \\
\hline
\end{tabular}




\section{Correlation of Emotional Intelligence with Conflict Management Styles in IT based Organization}

\begin{tabular}{|c|c|c|c|c|c|c|c|c|c|c|c|c|c|c|c|c|c|}
\hline & & 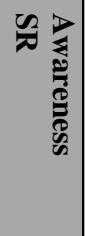 & 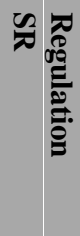 & 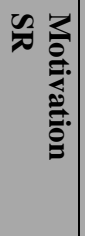 & 栆罚 & 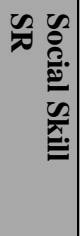 & 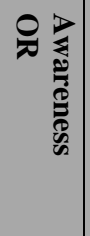 & 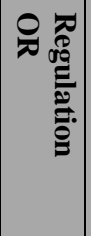 & 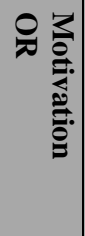 & 읶 & 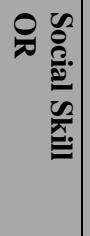 & 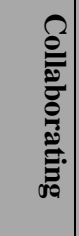 & 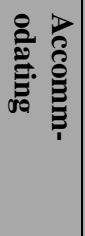 & 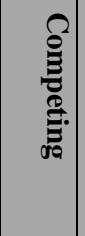 & 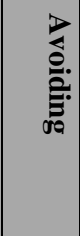 & 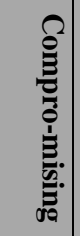 & $\underset{d}{\overrightarrow{0}}$ \\
\hline \multirow{3}{*}{ 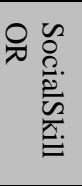 } & \begin{tabular}{|l|} 
Pearson \\
Correlation
\end{tabular} & .109 & .121 & .082 & .139 & $.220^{*}$ & $.306^{* *}$ & $.634^{* *}$ & .534 & .714 & 1 & -.020 & $.107^{*}$ & $103^{* *}$ & $.083^{* *}$ & .098 & .033 \\
\hline & \begin{tabular}{l|} 
Sig. (2- \\
tailed)
\end{tabular} & .280 & .231 & .420 & .167 & .028 & .002 & .000 & .000 & .000 & & .845 & .288 & .306 & .413 & .334 & .743 \\
\hline & $\mathrm{N}$ & 100 & 100 & 100 & 100 & 100 & 100 & 100 & 100 & 100 & 100 & 100 & 100 & 100 & 100 & 100 & 100 \\
\hline \multirow{3}{*}{ 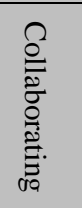 } & $\begin{array}{l}\text { Pearson } \\
\text { Correlation }\end{array}$ & .170 & .088 & .192 & .066 & .088 & .034 & .033 & .036 & .059 & -.020 & 1 & .499 & .430 & .321 & .264 & .118 \\
\hline & $\begin{array}{l}\text { Sig. (2- } \\
\text { tailed) }\end{array}$ & .091 & .383 & .056 & .516 & .385 & .733 & .743 & .721 & .560 & .845 & & .000 & .000 & .001 & .008 & .242 \\
\hline & $\mathrm{N}$ & 100 & 100 & 100 & 100 & 100 & 100 & 100 & 100 & 100 & 100 & 100 & 100 & 100 & 100 & 100 & 100 \\
\hline \multirow{3}{*}{ 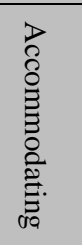 } & \begin{tabular}{l|} 
Pearson \\
Correlation
\end{tabular} & .176 & .068 & $.221^{*}$ & .169 & .089 & .149 & .196 & .133 & .040 & $.107^{*}$ & .499 & 1 & .444 & .369 & .290 & .016 \\
\hline & \begin{tabular}{l|} 
Sig. (2- \\
tailed)
\end{tabular} & .080 & .500 & .027 & .092 & .381 & .139 & .051 & .188 & .691 & .288 & .000 & & .000 & .000 & .003 & .876 \\
\hline & $\mathrm{N}$ & 100 & 100 & 100 & 100 & 100 & 100 & 100 & 100 & 100 & 100 & 100 & 100 & 100 & 100 & 100 & 100 \\
\hline \multirow{3}{*}{ 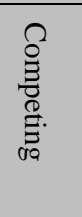 } & \begin{tabular}{l|} 
Pearson \\
Correlation
\end{tabular} & .083 & .112 & .167 & .141 & .190 & .099 & .104 & .134 & .143 & .103 & .430 & .444 & 1 & .329 & .386 & -.083 \\
\hline & \begin{tabular}{l|} 
Sig. (2- \\
tailed)
\end{tabular} & .414 & .265 & .098 & .163 & .059 & .330 & .302 & .185 & .157 & .306 & .000 & .000 & & .001 & .000 & .413 \\
\hline & $\mathrm{N}$ & 100 & 100 & 100 & 100 & 100 & 100 & 100 & 100 & 100 & 100 & 100 & 100 & 100 & 100 & 100 & 100 \\
\hline \multirow{3}{*}{ 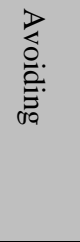 } & $\begin{array}{l}\text { Pearson } \\
\text { Correlation }\end{array}$ & .145 & .012 & .102 & .015 & .104 & -.081 & .113 & -.029 & .011 & .083 & .321 & .369 & 329 & 1 & -.331 & -.045 \\
\hline & $\begin{array}{l}\text { Sig. (2- } \\
\text { tailed) }\end{array}$ & .150 & .903 & .313 & .878 & .303 & .426 & .262 & .778 & .910 & .413 & .001 & .000 & .001 & & .001 & .657 \\
\hline & $\mathrm{N}$ & 100 & 100 & 100 & 100 & 100 & 100 & 100 & 100 & 100 & 100 & 100 & 100 & 100 & 100 & 100 & 100 \\
\hline \multirow{3}{*}{ 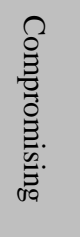 } & $\begin{array}{l}\text { Pearson } \\
\text { Correlation }\end{array}$ & -.050 & .063 & .051 & .109 & .065 & .183 & .038 & .202 & .097 & .098 & .264 & .290 & .386 & -.331 & 1 & .134 \\
\hline & $\begin{array}{l}\text { Sig. (2- } \\
\text { tailed) }\end{array}$ & .624 & .536 & .613 & .279 & .518 & .069 & .706 & .044 & .336 & .334 & .008 & .003 & .000 & .001 & & .185 \\
\hline & $\mathrm{N}$ & 100 & 100 & 100 & 100 & 100 & 100 & 100 & 100 & 100 & 100 & 100 & 100 & 100 & 100 & 100 & 100 \\
\hline \multirow[t]{3}{*}{$\underset{D}{\substack{D \\
D}}$} & $\begin{array}{l}\text { Pearson } \\
\text { Correlation }\end{array}$ & -.013 & .097 & .093 & .191 & .172 & .118 & .075 & -.036 & -.048 & .033 & .118 & .016 & -.083 & -.045 & .134 & 1 \\
\hline & $\begin{array}{l}\text { Sig. (2- } \\
\text { tailed) }\end{array}$ & .895 & .337 & .358 & .057 & .086 & .243 & .459 & .725 & .635 & .743 & .242 & .876 & .413 & .657 & .185 & \\
\hline & $\mathrm{N}$ & 100 & 100 & 100 & 100 & 100 & 100 & 100 & 100 & 100 & 100 & 100 & 100 & 100 & 100 & 100 & 100 \\
\hline
\end{tabular}

How to cite this article: G Khokhar, W Selvamurthy (2016), Correlation of Emotional Intelligence with Conflict Management Styles in IT based Organization, International Journal of Indian Psychology, Volume 3, Issue 4, No. 60, ISSN 2348-5396 (e), ISSN: 2349-3429 (p), DIP: 18.01.079/20160304, ISBN: 978-1-365-26308-8 